EAJ (Economic and Accounting Journal)

Vol. 4, No. 1, Jan. 2021

ISSN 2615-7888

Received: Sept. 14,2020; Revised: Jan. 15, 2021; Accepted: Jan. 26, 2021; Published: Jan. 31, 2021

\title{
THE EFFECT OF TAX AVOIDANCE AND DIVIDEND POLICIES ON COMPANY VALUE WITH LEVERAGE AS MODERATION VARIABLES
}

\author{
${ }^{\mathbf{1}}$ Muhammad Rizal Saragih, ${ }^{\mathbf{2}}$ Rusdi \\ Department of S1 Accounting, Universitas Pamulang \\ Email: rizalsaragih1990@gmail.com
}

\begin{abstract}
A high increase in company value is a long-term goal that must be achieved by a company, which is reflected in the market price of its shares because investors' assessment of the company can be seen through the movement of the stock prices of companies listed on the stock exchange. stock exchange for companies that have gone public. This has an impact on shareholders to maintain their investment and potential investors are interested in investing in the company. This study aims to analyze the effect of tax avoidance and dividend policy on firm value with leverage as a moderating variable. The population in this study were manufacturing companies listed on the Indonesia Stock Exchange from 2016 to 2018, totaling 166 companies, while the sample of this study was 18 companies with a purposive sampling method. The research method used is descriptive statistics, classic assumption testing and hypothesis testing multiple linear regression analysis. The results show that tax avoidance is not significant to firm value, dividend policy has a significant effect on firm value, leverage does not moderate tax avoidance on firm value, leverage. does not moderate dividend policy on firm value, and tax avoidance and dividend policy affect firm value.
\end{abstract}

Keywords: Tax Avoidance; Dividen Policy; Company Value; Leverage

\section{INTRODUCTION}

Efforts to increase firm value are tax avoidance. Tax avoidance or resistance to taxes are the obstacles that occur in tax collection, resulting in reduced state cash receipts. Tax avoidance which is carried out by exploiting loopholes in tax laws that have not regulated it is popular by using financial instruments. But from the perspective of taxpayers, paying taxes is a factor that can reduce their income, let alone the stigma of society that until now has not felt the impact directly. The manufacturing industry classifies several sectors, namely the goods and consumption 
industry sector, various industries, basic and chemical sectors.

The lack of clear regulations regarding tax avoidance creates different perceptions between the government and the taxpayer. When viewed from the taxpayer's point of view, as long as personal or corporate taxpayers have a way of minimizing taxes and there are no definite regulations regarding tax violations, then things that are done are fine or legal. Meanwhile, from the government, the existing regulations regarding tax payments are expected not to be abused by avoiding taxation or by minimizing corporate taxes for profit.

Based on a report made jointly by Ernesto Crivelly, an investigator from the IMF in 2016, based on a survey, then re-analyzed by the UN University using the database of the International Center for Policy and Research and the International Center for Taxation and Development (ICTD) published data on corporate tax avoidance from 30 countries. Indonesia is ranked 11th with an estimated value of US $\$ 6.48$ billion, corporate taxes are not paid by companies in Indonesia to the Indonesian Tax Office. Tax evasion is a serious problem in Indonesia. It is estimated that every year there are IDR 11 trillion, which is the figure for tax avoidance. Most are business entities, about 80 percent, the rest are individual taxpayers. From the facts and phenomena described above, the researchers are therefore interested in conducting a study entitled. And Research results Jesica and Francis show that there is no effect of dividend policy on firm value and tax avoidance has a considerable influence on firm value, (Andriyani, J., \& Hutabarat, F. (2020). So that there is an inconsistency in the results of the research that makes researchers interested in taking the title.

\section{LITERATURE REVIEW AND HYPOTHESIS DEVELOPMENT}

\section{Tax Avoidance.}

Tax avoidance is a scheme that is shown to carry out the tax burden by taking advantage of the weaknesses (loophole) of a country's taxation provisions so that tax experts claim legal statements because they do not violate tax regulations. Taxpayers who only understand taxes as duty will encourage them to try in such a way as to keep their tax burden to a minimum, (Irawati, W., et al., 2020).

\section{Dividend Policy.}

Dividend policy is a policy where investors have the main goal of improving welfare by expecting returns in the form of dividends and capitail gains, (Utami \& Darmayanti, 2018). Dividend policy is a decision whether the profits earned by the company at the end of the year will be distributed to shareholders in the form of dividends or will be retained to increase capital for investment 
financing in the future, (Akbar Firmansyah, 2019: 15). A dividend policy is a company policy regarding how much profit earned will be paid out as dividends and profits that will be retained to be reinvested in the company, (Putri, N. R., \& Irawati, W. (2019). Dividend policy can be defined as the distribution of the company's net profit which is distributed to shareholders with the approval of the General Meeting of Shareholders, (Hery, 2015). Share dividend announcements will be recorded in the journal by debiting the share dividend account (equal to the current fair market value of the shares to be distributed or issued later) and crediting the stock dividend distributable account (in the amount of value of the shares to be issued).

Management has 2 alternative treatments for net income after corporate tax:

1. shareholders of the company given in the form of dividends

2. companies can invest as income. So it can be concluded that the definition of dividend policy is the management's decision to determine the treatment of Earning After Tax which is distributed as dividends.

\section{The value of the company.}

Company Value is the ratio of market value that describes the conditions that occur in the market, this market is able to provide an understanding for the company's management of the implementation conditions to be implemented and their impact in the future. Value of the company can also be seen from its ability to pay dividends to the owner of the company, (Murniati, S., et al., 2019). According to (Akbar Firmansyah, 2019: 25), company value is investors' perception of companies which are often associated with stock prices. A high share price makes the company value high, and the high company value makes the market believe not only in the company's current performance but also in the company's future prospects, (Brigham, E. F., \& Daves, P. R., 2014).

\section{Leverage.}

Leverage is the use of assets and sources of funds by companies that have fixed costs (fixed expenses) with the aim of increasing shareholder profits, (Siti Argaeni, 2019: 53).

The company issues common stock or preferred stock, so the burden to be borne is dividends that must be paid to shareholders. The company uses machines, buildings, so the company must pay fixed costs in the form of defreciation of these assets. The higher the level of leverage, the more likely it will violate the credit agreement, so that companies will try to report higher profits by reducing costs including the cost of social or corporate equipment, (Siti Argaeni, 2019: 56).

Leverage is to measure how much a company is financed by debt. 
The use of debt that is too high will endanger the company because the company will fall into the extreme leverage category, (Irham, F., 2015). Firms are better suited to debt if the leverage is high in financing company assets. Companies that use debt will incur interest expenses to be paid. The greater the debt the company pays, the higher the interest expense that must be paid.

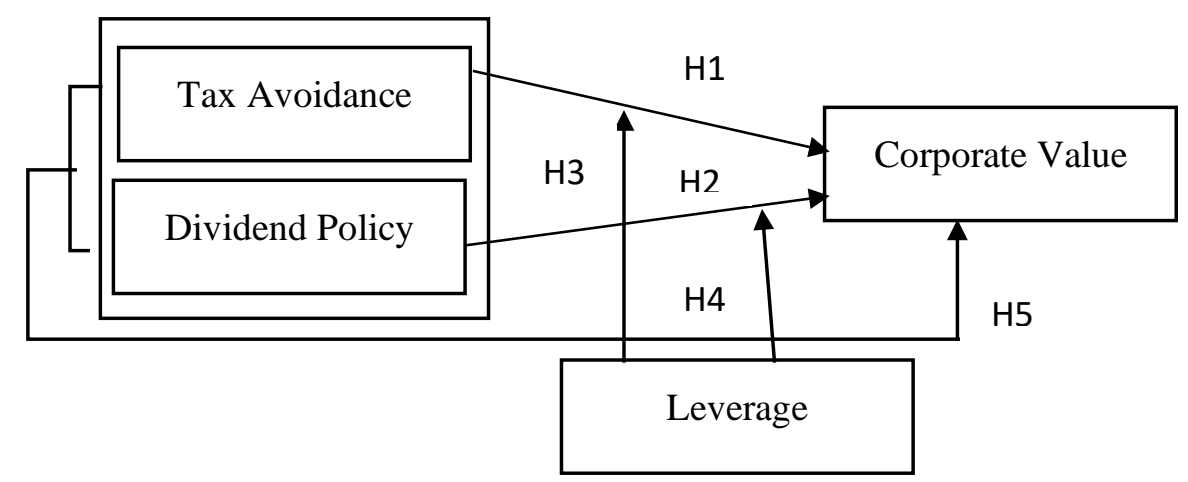

Figure 1. Research Framework

\section{RESEARCH METHOD}

\section{Data Collection Techniques.}

States that the research design must be specific, clear and detailed, determined steadily from the start, become a step-by-step guide. In this study, researchers used quantitative research methods with secondary data and analysis. The quantitative research method is a research method based on the philosophy of positivism, used to research on certain populations or samples, data collection uses the objective of testing predetermined hypotheses, (Sugiyono, 2015). This research method is descriptive.

\section{Operational Definitions of} Variables.
Measurement variables are objects or activities that have certain variables set by researchers to study and draw conclusions, (Sugiyono, 2015). The variables in this study belong to three groups of variables, namely the dependent variable, the independent variable and the moderating variable. The dependent variable in this study company value (Y) is a ratio that shows the comparison between market price per share and earnings per share according to (Hery, 2015: 169). The independent variable tax avoidance (X1) is a scheme that is shown to carry out the tax burden by taking advantage of the weaknesses. and dividend policy (X2) is a decision whether the profits earned by the company at the end of the year will be distributed to shareholders in the form 
EAJ (Economics and Accounting Journal) - Vol. 4, No. 1, Jan 2021 -Saragih \& Rusdi

of dividends, and the moderating variable leverage $(\mathrm{Z})$ is use of assets and sources of funds by companies that have fixed costs (fixed expenses) with the intention of increasing shareholder profits.

\section{Sample Collection Techniques.}

Sampling in this study was carried out by purposive sampling. The purposive sampling method is the sampling chosen based on the suitability of the characteristics with the specified sample criteria. The selection criteria in this study are: Number of samples during the study period 72, Data experiencing outliers 18 and Total Samples 54.

Based on the above criteria, the sample size of the study was 24 companies from 166 manufacturing companies listed on the Indonesia Stock Exchange. However, due to the absence of normal data, this study experienced an outlier of 6 companies, (Ghozali, I. (2016).

\section{Data Analysis Techniques}

The data used in this research is secondary data. Secondary data is data that does not directly provide data to researchers, for example, researchers must go through other people or search through documents. Secondary data obtained from the company's annual financial reports published on the Indonesia Stock Exchange website, namely www.idx.co.id.

\section{RESULTS AND DISCUSSION}

\section{Results}

\section{Classic assumption test}

The results of the One Sample Kolmogorov-Smirnov Test show that the regression meets the normality assumption shown in Asymp.Sig. (2tailed) $0.200>0.05$. The result of calculating the Variance Inflation Factor value (VIF) on tax avoidance of 1.093 and dividend policy of 1.093 shows that none of the variables has a VIF value of more than 10 . The Glejser test produces a significant value of the tax avoidance variable of 0.712 , the dividend policy variable is 0.821 , which means that the significance value of each of these variables is greater than the alpha value of 0.05 . So it can be concluded that heteroscedasticity does not occur. The Durbin-Watson value shows a value of 1.127 or it can be said that it fulfills the second assumption, namely the value lies between -2 to +2 . that is, where the value is -2 $<1.127<+2$, so it can be concluded that there is no autocorrelation in the data in this study.

\section{Partial Significance Test (t Statistical Test).}

The $t$ statistical test basically shows how far the influence of one independent variable is in explaining the variation of the dependent variable, (Ghozali, 2016). The $\mathrm{t}$ statistical test is used to see the significance of the effect of the independent variable individually on 
the dependent variable by assuming other variables are constant. In this study using a significance level of $0.05(\alpha=5 \%)$.

The results of testing the $\mathrm{t}$ statistical hypothesis test between the effects of tax avoidance and dividend policy on firm value are as follows:

1. The Effect of Tax Avoidance on Firm Value (H1).Based on the table, it is known that tax avoidance has a significant value of 0.307 where the value is $0.307>$ 0.05 and the tcount is 1.033 $<2.00665$. These results indicate that tax avoidance has no partial and negative significant effect on firm value. So that $\mathrm{H} 1$ is rejected.

2. Effect of Dividend Policy on Firm Value (H2). Based on table it is known that the dividend policy has a significant value of 0.000 where the value is $0.000<0.05$ and the tcount is $3,934>2,00665$. These results indicate that dividend policy has a partial and positive significant effect on firm value. So that $\mathrm{H} 2$ is accepted.

3. Leverage as a Moderation variable can Strengthen or Weaken the effect of Tax Avoidance on Firm Value (H3). The results of $t$ statistical testing between the effect of tax avoidance on firm value with leverage as a moderating variable are as follows: the test results found that the significance probability value (0.454>0.05) means that leverage as a moderating variable of tax avoidance has no significant effect on firm value. The $\mathrm{t}$ value shows negative, namely $(-0.755$ $<2.00665)$ for that, the third hypothesis (H3) states that leverage as a moderating variable (Z) can weaken the influence of the independent variable tax avoidance (X1) on the dependent variable firm value (Y) at the company. manufacturers listed on the Indonesia Stock Exchange (IDX) for the period 2016-2018.

4. Leverage as a Moderation variable can Strengthen or Weaken the influence of Dividend Policy on Firm Value (H4). In the test results table, it is found that the value of probability significance (0.219> $0.05)$ means that leverage as a moderate variable dividend policy does not have a significant effect on firm value. The $t$ value shows positive, namely $(1.244<2.00665)$ for that, the fourth hypothesis (H4) states that leverage as a moderating variable (Z) can weaken the influence of the independent variable dividend policy (X2) on the dependent variable firm value (Y) in manufacturing companies. listed on the Stock Exchange in Indonesia (IDX) for the period 2016-2018.

\section{Simultaneous Significance Test (Test Statistic F).}

The $\mathrm{f}$ statistical test shows whether all the independent variables included in the model have a joint influence on the dependent variable, 
(Ghozali, 2016). The decision making criteria in this test is to use a quick look, which means that Ho can be rejected at a level of confidence of $5 \%$ if the $\mathrm{F}$ value is greater than 4 and compares the calculated $F$ value with the $\mathrm{F}$ table, which means that if the $\mathrm{F}$ count $>\mathrm{F}$ table then Ho is rejected and accepts HA.
The Effect of Tax Avoidance and Dividend Policy on Company Value (H5).

The results of testing the $\mathrm{F}$ statistical hypothesis test between the effects of tax avoidance and dividend policy on firm value are as follows:

Tabel 1 F-Test Result ANOVAa

\begin{tabular}{|l|r|r|r|r|r|}
\hline \multicolumn{1}{|c|}{ Model } & Sum of Squares & df & Mean Square & F & Sig. \\
\hline Regression & 658,492 & 2 & 329,246 & 10,335 &, $000^{\mathrm{b}}$ \\
Residual & 1624,692 & 51 & 31,857 & & \\
Total & 2283,184 & 53 & & & \\
\hline
\end{tabular}

a. Dependent Variable: Company Value

a. Predictors: (Constant), Dividend Policy, Tax Avoidance

Source: Data processed by SPSS 22.0 program

In the test results table, it is obtained that the value of $\mathrm{F}$ count $>\mathrm{F}$ table or $(10.335>3.18)$, this is reinforced by a significance probability value $(0.000$ $<0.05)$ which means that it is influential or accepted. For this reason, the first hypothesis $(\mathrm{H} 1)$ states that the independent variable tax avoidance (X1) and dividend policy (X2) simultaneously affects the dependent variable firm value (Y). Thus, it can be concluded that tax avoidance and dividend policy have a simultaneous effect on firm value.

\section{Discussion}

\section{The Effect of Tax Avoidance on Firm Value (H1).}

Tax avoidance has a significant value of 0.307 where the value is $0.307>0.05$ and the tcount is 1.033 $<2.00665$. These results indicate that tax avoidance has no partial and negative significant effect on firm value. So that $\mathrm{H} 1$ is rejected. it means that tax avoidance has no effect on firm value. that tax avoidance has a significant negative effect on firm value. This is in line with previous research with the research results that tax avoidance has a significant negative effect on the value of the company. Meanwhile, in other research shows that tax avoidance has a positive effect on firm value.

\section{Effect of Dividend Policy on Firm Value (H2).}

The dividend policy has a significant value of 0,000 where the value is $0,000<0.05$ and the tcount is 3,934> 2,00665. These results indicate that dividend policy has a partially and positively significant 
effect on firm value. So that $\mathrm{H} 2$ is accepted. then it can be interpreted that dividend policy affects firm value. This is in line with previous research conducted by Dahela with the results of research that dividend policy has a significant positive effect on firm value, (Dahela, 2018).

Leverage as a Moderation variable can Strengthen or Weaken the effect of Tax Avoidance on Firm Value (H3).

In the test results table, it is found that the value of probability significance $(0.454>0.05)$ means that leverage as a moderating variable of tax avoidance has no significant effect on firm value. The $\mathrm{t}$ value shows negative, namely (-0.755 $<2.00665)$ for that the third hypothesis (H3) which states that leverage as a moderating variable $(\mathrm{Z})$ can weaken the influence of the independent variable tax avoidance (X1) on the dependent variable firm value (Y) at the company. manufacturers listed on the Indonesia Stock Exchange (IDX) for the period 2016-2018. This is in line with previous research conducted by Soerzawa, et al with the results of research that leverage does not moderate the relationship between tax avoidance and firm value. it means that leverage weakens the relationship between tax avoidance and firm value, (Soerzawa, et al., 2018).

\section{Leverage as a Moderation variable can Strengthen or Weaken the}

influence of Dividend Policy on Firm Value (H4).

In the test results table, it is found that the value of probability significance $(0.219>0.05)$ means that leverage as a moderating variable of dividend policy has no significant effect on firm value. The $\mathrm{t}$ value shows $(1.244<2.00665)$ for that the fourth hypothesis (H4) which states that leverage as a moderating variable (Z) can weaken the influence of the independent variable dividend policy (X2) on the dependent variable firm value (Y) in listed manufacturing companies. on the Indonesia Stock Exchange (IDX) for the period 20162018. it means that leverage weakens the relationship between dividend policy and firm value.

\section{The Effect of Tax Avoidance and Dividend Policy on Firm Value (H5).}

In the test results table, it is obtained that the value of $\mathrm{F}$ count $>\mathrm{F}$ table or (10.335> 3.12), this is reinforced by the significance probability value $(0.000<0.05)$ which means that it is influential or accepted. For this reason, the fifth hypothesis (H5) states that the effect of the independent variable tax avoidance (X1) and dividend policy (X2) simultaneously on the dependent variable firm value (Y) in manufacturing companies listed on the Indonesia Stock Exchange (IDX) for the period 2016-2018. Thus, it can be concluded that tax avoidance and 
EAJ (Economics and Accounting Journal) - Vol. 4, No. 1, Jan 2021 -Saragih \& Rusdi

dividend policy have a simultaneous effect on firm value.

\section{CONCLUSION}

The results indicate that tax avoidance has no partial and negative significant effect on firm value. The results indicate that dividend policy has a partial and positive significant effect on firm value. The results indicate that leverage as a moderating variable weakens tax avoidance towards firm value. The results indicate that leverage as a moderating variable weakens dividend policy on firm value. The results indicate that tax avoidance and dividend policy have a significant and positive effect simultaneously on firm value.

Researchers only use 2 independent variables, namely tax avoidance and dividend policy, and a moderating variable, namely leverage on firm value. Meanwhile, there are other explanatory variables that affect firm value so that these 4 variables do not cover all the factors that affect firm value.

\section{REFERENCES}

Andriyani, J., \& Hutabarat, F. (2020). Pengaruh Kebijakan Dividen terhadap Nilai Perusahaan dengan Variabel Mediasi Penghidaran Pajak pada Perusahaan Property. Jurnal
Akuntansi Dan Investasi, 5(2), 151-159.

Argaeni, S. (2019). Pengaruh Leverage, Kepemilikan Institutional, Capital Intensity Dan Ukuran Perusahaan Terhadap Tax Avoidance Dampaknya Pada Profitabilititas (Doctoral dissertation, Universitas Pamulang).

Brigham, E. F., \& Daves, P. R. (2014). Intermediate financial management. Cengage Learning.

Dahela. (2018). Pengaruh Tax Planning, Kebijakan Hutang dan Kebijakan Dividen Terhadap Nilai Perusahaan. Jurnal Ekonomi Universitas Pamulang, 4(2), 1-13.

Firmansyah, A., Ardi, A. K. (2020). Related party transactions, supply chain and cost management on firm's value: evidence from Indonesia. International Journal of Supply Chain Management, 9(3), 12011209.

Ghozali, I. (2016). Aplikasi Analisis Multivariete dengan Program IBM SPSS 23. Semarang: Badan Penerbit Universitas Diponegoro.

Hery. (2015). Analisis Laporan Keuangan Pendekatan Rasio Keuangan. Yogyakarta: CAPS

Irham, F. (2015). Pengantar Manajemen Keuangan, cetakan 
EAJ (Economics and Accounting Journal) - Vol. 4, No. 1, Jan 2021 -Saragih \& Rusdi

keempat. Penerbit Alfabeta, Bandung.

Irawati, W., Akbar, Z., Wulandari, R., \& Barli, H. (2020). Analisis Profitabilitas, Leverage, Pertumbuhan Penjualan Dan Kepemilikan Keluarga Terhadap Penghindaran Pajak. JAK (Jurnal Akuntansi): Kajian Ilmiah Akuntansi, 7(2), 190-199

Murniati, S., Mus, H. A. R., Semmaila, H. B., \& Nur, A. N. (2019). Effect of investment decisions, financing decisions and dividend policy on profitability and value of the firm. International Journal of Accounting \& Finance in Asia Pasific (IJAFAP), 2(1).

Putri, N. R., \& Irawati, W. (2019). Pengaruh Kepemilikan Manajerial dan Effective Tax
Rate terhadap Kebijakan Dividen dengan Likuiditas sebagai Variabel Moderating. Jurnal Kajian Akuntansi, 3(1), 93-108.

Soerzawa, D., Yusmaniarti, Y., \& Suhendra, C. (2018). Pengaruh Penghindaran Pajak Terhadap Nilai Perusahaan Dengan Leverage Sebagai Variabel Moderasi. Bilancia: Jurnal Ilmiah Akuntansi, 2(4), 367-377.

Sugiyono. (2015). Metode Penelitian Pendidikan Pendekatan Kuantitatif, Kualitatif dan $R \& D$. Bandung: Alfabeta.

Utami, A. P. S., \& Darmayanti, N. P. A. (2018). Pengaruh Keputusan Investasi, Keputusan Pendanaan dan Kebijakan Dividen Terhadap Nilai Perusahaan Food and Beverages. E-Jurnal Manajemen, 7(10), 5719-5747. 